\title{
Mechanical site preparation: Key to microsite creation success on Clay Belt paludified sites
}

\author{
by Mohammed Henneb1", Osvaldo Valeria', Nicole J. Fenton¹, Nelson Thiffault ${ }^{2}$ and Yves Bergeron ${ }^{1}$
}

\begin{abstract}
Paludification is the accumulation of partially decomposed organic matter over saturated mineral soils. It reduces tree regeneration and growth, mainly because of low temperatures and high water content in the rooting zone, reduced organic matter decomposition, and hence, low nutrient availability. On the Clay Belt of western Québec and eastern Ontario, forests tend to paludify naturally but this process might be promoted by logging methods. Our objective was to identify which of two commonly used mechanical site preparation (MSP) techniques is best adapted to reduce organic layer thickness (OLT) and generate favourable planting microsites post-harvest in paludified sites. Nine experimental blocks (between 20 ha-61 ha each) were delimited within a $35 \mathrm{~km}^{2}$ forest sector with variable levels of paludification. The forest sector was harvested by careful logging to protect advance growth and soils and subsequently the nine experimental blocks were treated with either forest harrowing, disc trenching (T26) or left as untreated controls (harvesting only) with three replicate blocks per treatment. We measured OLT before and after MSP and determined planting microsite quality within each block. Results revealed significant differences in OLT between MSP treatments and harvesting only. Overall, harrowing was the best technique, as it reduced OLT more than T26 scarification and generated the highest percent of good microsites, except where initial OLT was $44 \mathrm{~cm}-56 \mathrm{~cm}$. Our results contribute to the successful use of MSP in paludified forests.
\end{abstract}

Keywords: paludification, peat, organic layer thickness, mechanical site preparation, microsites, boreal forest management.

\section{RÉSUMÉ}

La paludification est l'accumulation de la couche organique partiellement décomposée sur le sol minéral saturé en eau. La paludification réduit la régénération et la croissance des arbres, principalement en raison des faibles températures et la teneur élevée en eau dans la zone racinaire, réduisant ainsi la décomposition de la couche organique, et par conséquent, la disponibilité des éléments nutritifs. Dans la Ceinture d’Argile de l'ouest du Québec et l'est de l'Ontario, les forêts tendent vers une paludification naturellement, mais ce processus pourrait être contré par des méthodes d'exploitation forestière. Notre objectif était d'identifier laquelle des deux techniques de préparation mécanique du terrain (PMT) couramment utilisées est la mieux adaptée pour réduire lépaisseur de la couche organique (ECO) et générer des microsites de plantation favorables après récolte dans les sites paludifiés. Neuf blocs expérimentaux (entre 20 ha-61 ha chacun) ont été délimités dans un secteur forestier de $35 \mathrm{~km}^{2}$ avec des niveaux variables de paludification. Le secteur a été récolté en utilisant la coupe avec protection de la régénération et des sols (CPRS). Les neuf blocs expérimentaux ont ensuite été traités avec une herse forestière, un scarificateur à disques (T26) ou laissés comme témoins non traités (récolte seulement), avec trois blocs répétés par traitement. Nous avons mesuré l'ECO avant et après PMT et déterminé la qualité des microsites à l'intérieur de chaque bloc. Les résultats ont révélé des différences significatives d'ECO entre les traitements de PMT et la récolte seulement. Globalement, la herse forestière était la meilleure technique de PMT, car cette dernière a réduit davantage l'ECO que le scarificateur T26 et a généré le pourcentage le plus élevé de bons microsites, sauf dans le seuil d'ECO initiale 44 $\mathrm{cm}-56 \mathrm{~cm}$. Nos résultats favorisent l'utilisation réussie de la PMT dans les forêts paludifiées.

Mots clés: paludification, tourbe, épaisseur de la couche organique, préparation mécanique du terrain, microsites, gestion de la forêt boréale.

\footnotetext{
${ }^{1}$ Forest Research Institute, NSERC-UQAT-UQAM Industrial Chair in Sustainable Forest Management. Université du Québec en AbitibiTémiscamingue. 445, boul. de l'Université, Rouyn-Noranda, Québec, J9X 5E4

*corresponding author (Mohammed.henneb@uqat.ca)

${ }^{2}$ Direction de la recherche forestière, Ministère des Forêts, de la Faune et des Parcs, 2700 rue Einstein, Québec, Québec, G1P 3W8
} 


\section{Introduction}

Decline in forest productivity has received increasing attention in recent decades because of its potential influence on global carbon budgets and sustainable forest management (Ryan et al. 2004). In boreal ecosystems, one of the causes of forest productivity decline is the accumulation over time of thick organic layers over mesic mineral soils (Sirén 1955), a phenomenon known as "paludification". Paludification is mainly due to an increase in the water table level, leading to cold anaerobic conditions, which in turn reduces microbiological activity (Comont 2006, Bergeron et al. 2007) and limits mineralization and nutrient uptake by plants (Gower et al. 1996, Prescott et al. 2000, Fenton et al. 2005, Lavoie et al. 2005). Paludifcation can be edaphic (permanent) or successional, primarily due to topographic position and drainage potential. Depressions with no drainage and toe slopes are strongly associated with deep organic layers and may lead to permanent paludification (Laamrani et al. 2015). In this case, a high input of resources, such as forest drainage (Jutras et al. 2007), is needed to change its state and consequently such areas present little economic potential. In contrast, successional paludification occurs in topographic positions with drainage potential, e.g., plateaus, mid-slopes, and open depressions (Laamrani et al. 2015). Paludification on these sites is associated with dynamic processes that can be reversed.

In the boreal forests of eastern Canada, paludification is a natural phenomenon; consequently, organic layer thickness (OLT) frequently exceeds $30 \mathrm{~cm}$ and it may be even more important in some regions such as the Clay Belt (Simard et al. 2007, 2009). This region, which extends over $125000 \mathrm{~km}^{2}$ in northern Québec and Ontario is dominated by black spruce (Picea mariana (Mill.) BSP) stands and is characterized by low undulating hills and soils with a high clay content that impedes drainage (Payette 2001). Stands frequently established on paludified sites have low productivity and deficient regeneration (Simard et al. 2007). The organic layer in these paludified sites is composed of partially decomposed feather mosses and Sphagnum spp. (Salemaa et al. 2008) that gradually accumulate as an insulating layer over the mineral soil. The accumulation of bryophytes effects soil temperature, moisture and nutrient availability, with cascading impacts on other ecosystem processes such as net primary production (Lafleur et al. 2011). Consequently, over time the forest becomes unproductive (Simard et al. 2007).

Although forest succession in the Clay Belt tends naturally to paludification, this process might be further promoted by logging methods such as logging with protection of advance growth and soils (in Québec, coupe avec protection de la régénération et des sols, referred to as CPRS). This harvesting method is mainly applied in winter when bearing capacity of the soil is low as is frequently the case on the Clay Belt; this further reduces harvesting impact on the soil (Lafleur et al. 2010). Moreover, machinery passes are restrained to regularly spaced trails that account for a maximum of $25 \%-33 \%$ of the surface area of cutovers (Harvey and Brais 2002). Lafleur et al. (2010) have shown that this disturbance is insufficient in terms of spatial distribution and impact on the organic layer reduction to guarantee the return of productive stands on paludified sites. On the other hand, mechanical site preparation (MSP) techniques, such as disking and forest harrowing (commonly used for mechanical site preparation in Québec), may mix the organo-mineral layer and reduce competition cover (Löf et al. 2012). In addition, Prévost and Dumais (2003) showed that after harvest and MSP, some natural regeneration remains and demonstrates a significant gain in growth.

In paludified conditions, such as those found on the Clay Belt, mechanical site preparation is thus expected to generate favorable microsites for species regeneration and growth by either exposing the mineral soil or offering a suitable mix of organic and mineral substrates (Lafleur et al. 2010). However, MSP techniques are also expected to differ in their capacity to reduce OLT and create appropriate regeneration microsites; for example, forest harrowing is typically considered a more intense treatment than disking, which should constitute an advantage when treating paludified boreal sites (Thiffault et al. 2004). Given that site conditions have a major influence on the outcomes of MSP (Sutherland and Foreman 1995), it remains to be verified how harrowing and disking affect microsite abundance and quality on paludified sites.

Our study aimed to determine the efficiency of two MSP techniques (T26 disc scarification and forest harrowing) in reducing OLT and creating good regeneration microsites on paludified sites on the Clay Belt. We compared, in an operational context, the effects of MSP versus CPRS alone on the reduction of the OLT and the generation of good regeneration microsites. We predicted that MSP techniques would result in a significantly greater decrease in OLT compared to CPRS alone (Lafleur et al. 2010). We also investigated which MSP technique was the most effective in reducing OLT and creating good regeneration microsites, while taking into account initial OLT conditions. Our aim was to evaluate whether the T26 scarifier treatment provides results equivalent to the forest harrow treatment (Fig. 1) as observed in other studies conducted on sites characterized by thin OLT (Buitrago et al. 2014). Our hypothesis assumed that forest harrowing would provide better results in terms of OLT reduction and abundance of good microsites, compared to the T26 scarifier, due to the intense mixing of the organic and mineral horizons. Finally, we asked about the influence of topography on the efficiency of MSP to reduce OLT and create appropriate regeneration microsites. We predicted that steep slopes would limit the efficiency of MSP in that regard, given the operational constraints imposed by such conditions.

\section{Materials and Methods}

\section{Study area and experimental sites}

Nine study blocks, with an average area of 32 ha (from 20 ha-61 ha), were delimited in northwestern Québec (49 $28^{\prime}$ $\mathrm{N}, 78^{\circ} 30^{\prime} \mathrm{W}$ ) within the black spruce-feather moss bioclimatic domain described by Saucier et al. (2009; Fig. 2). The surficial deposit in this region is dominated by compacted clay and is associated with a significant peat cover interspersed with sand and gravel deposits of the Harricana Moraine (Veillette 1994). Average annual temperature and precipitation in the study region are $0.7^{\circ} \mathrm{C}$ and $906 \mathrm{~mm}$ respectively (Environment Canada 2011) as measured at the nearest weather station (100 km north-east in Matagami, Québec). Black spruce and jack pine (Pinus banksiana Lamb.) were the dominant species before harvest, constituting respectively $79 \%$ and $16 \%$ of the basal area. These species 


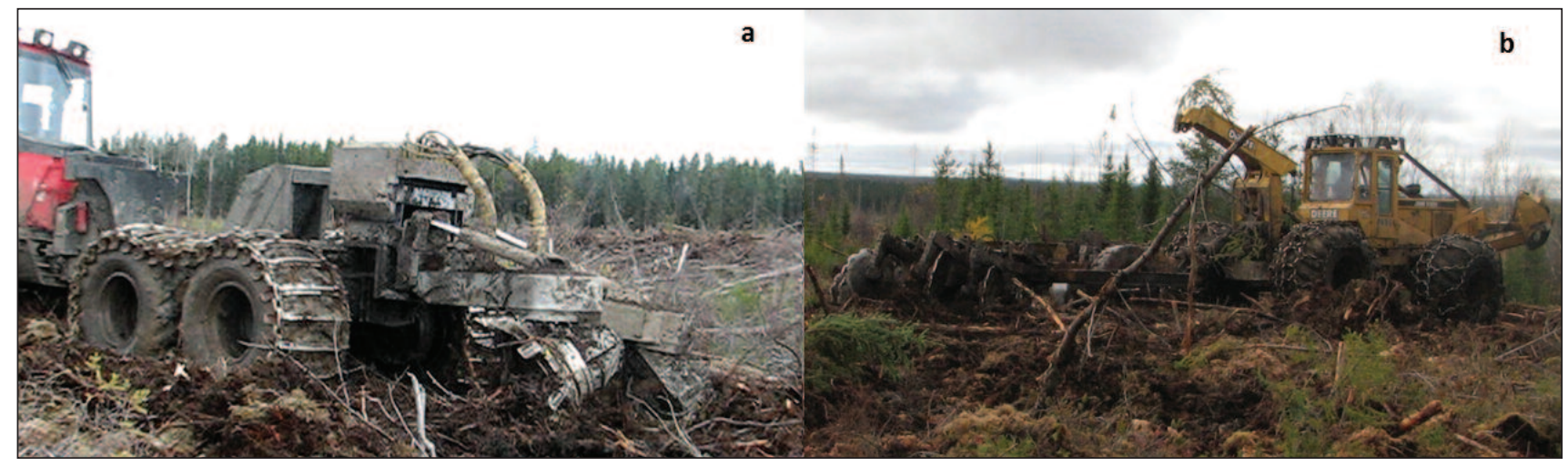

Fig. 1. (a) T26 Scarifier, a machine with two large, robust toothed discs. It is the most used site preparation machine in the boreal forest. (b) Forest harrow, multi-disc toothed machine, aligned in two rows. In Abitibi, it is used to prepare the clay soil forest sites and waste lands.

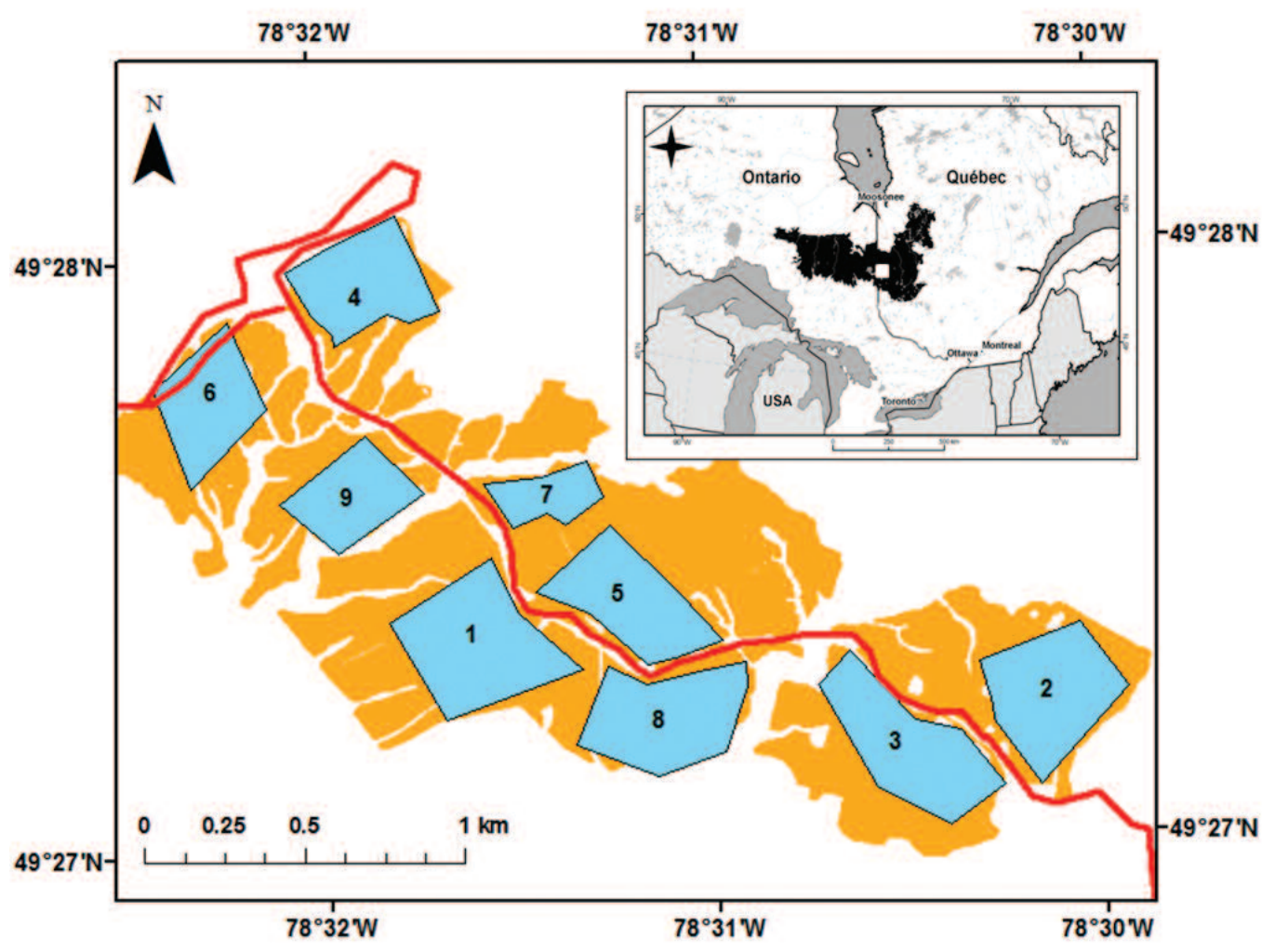

\begin{tabular}{l} 
Legend \\
$\square$ : Experimental Blocks \\
Block 2, 4, 7: Harvest + Harrowing \\
Block 3, 5, 9: Harvest + Disc trenching \\
Block 1,6, 8: Harvest only \\
$\square$ : Harvesting area \\
\hline : Forest road
\end{tabular}

Fig. 2. Study area location and distribution of treatments across experimental blocks. 
were followed by trembling aspen (Populus tremuloides Michx) which occupied about $4 \%$ of the basal area. The remaining $1 \%$ of the basal area was composed of larch (Larix laricina [ Du Roi ] K. Koch), balsam fir (Abies balsamea [L.] Miller), and paper birch (Betula papyrifera Marsh.) (Laamrani et al. 2013). The forest floor was composed of Sphagnum species (S. capillifolium, S. russowi, S. angustifolium) or feather moss (mainly Pleurozium schreberi (Brid.) Mitten and Ptilium crista-castrensis (Hedw.) De Not.) and shrubs (mainly Ericaceae) with a variable cover along the landscape (Laamrani et al. 2013).

\section{Data collection and sampling design}

We produced a digital terrain model (DTM) of the study area using LiDAR (Light Detection and Ranging) data collected over an area of $\sim 105 \mathrm{~km}^{2}$ that included the study blocks. The data were of high density $\left(2.8\right.$ points $\left./ \mathrm{m}^{2}\right)$, with a vertical accuracy (root mean square error) of $-0.065 \mathrm{~cm}$. LiDAR data were pretreated by separating pulse canopy returns from pulse returns to the ground. The last returns were classified as those of the surface above the ground and interpolated with a resolution of either 1,5 , or $10 \mathrm{~m}$ to produce the DTM using TIN with ArcGIS software (v. 10.0; ESRI 2011). Topographic variables (slope, aspect) were extracted from DTM over the study area at each resolution.

Organic layer thickness was assessed manually in 2009 (pre-harvest) along three transects covering a study zone that included the study blocks (Laamrani et al. 2014). Manual OLT measurements were performed every $20 \mathrm{~m}$ along transects with a graduated probe. Organic layer thickness for the entire area of the study blocks was obtained through inverse distance weighted interpolation using ArcGIS software.

The nine experimental blocks were harvested by CPRS in autumn 2010. Approximately twelve months later (autumn 2011), six of the nine blocks were selected to receive one of two MSP treatments, so that the entire OLT gradient was represented in each treatment type. Three blocks were treated by a forest harrow (perpendicular double pass) equipped with $0.91 \mathrm{~m}$-dia. discs, and three blocks were treated with a T26 scarifier (parallel double pass) equipped with two $1.35 \mathrm{~m}$-dia. discs (Fig. 1). Three blocks remained untreated (CPRS only) to serve as controls. The entire experiment was thus laid out as a complete block design with three treatments (Forest harrow, T26 scarifier and CPRS only) and three replicates (Fig. 2).

Organic layer thickness was measured manually along eight parallel, geo-referenced transects in each block after harvest and before MSP (summer 2011) and after MSP (summer 2012). Transects $\sim 400 \mathrm{~m}$ long, spaced $20 \mathrm{~m}$ from each other, were oriented perpendicularly to the harvest trails. Transects were located at least $60 \mathrm{~m}-80 \mathrm{~m}$ away from forest roads to avoid the impacts of forestry operations (e.g, delimbing, stacking) that are unrelated to the studied treatments. Manual OLT measurements were performed every $20 \mathrm{~m}$ along the transects with a graduated probe. During the summer of 2012, we also performed a qualitative assessment of regeneration microsites at each OLT measuring point along transects. A $1-\mathrm{m}^{2}$ grid divided into 25 quadrats of $20 \times 20 \mathrm{~cm}$ was used to describe microsite availability and quality. We considered each quadrat as a potential microsite, and qualified each of them as being of "good" or "bad" quality for planting purposes based on the provincial standards used in Québec for more than 120 million seedlings planted annually
(Thiffault 2005, MRNF 2006). Good microsites were composed of mineral soil mixed with organic matter or decomposed organic material: humified, mesic, humic-mesic mixture (Soil Classification Working Group 1998). Bad microsites were composed exclusively of mineral soil, either compacted or in unstable forms, or composed of poorly decomposed (fibric) organic materials. The good/bad microsites were converted to relative percentage for each quadrat. Microsite quality was expressed at the experimental block scale to represent a reliable and operational plantability coefficient.

\section{Statistical analyses}

All analyses were performed using the $\mathrm{R}$ system Version 2.15.0 ( $\mathrm{R}$ Development Core Team 2012), using $\alpha=0.05$ as a significance level threshold. Using pre-harvest OLT data (from 2009), we first verified OLT homogeneity across blocks before treatment (CPRS, T26 scarifier and forest harrow). Results showed a non-significant difference between treatments $(p>0.4$; forest harrow $=43.3 \pm 4.5 \mathrm{~cm}$; T26 scarifier $=$ $41.8 \pm 5.1 \mathrm{~cm}$; CPRS $=41.00 \pm 4 \mathrm{~cm}$ ), confirming homogeneous initial OLT across study blocks.

We performed Pearson correlations $\left(r_{p}\right)$ between initial OLT (2011) and topographic variables (slope and aspect) at three resolutions $(1 \mathrm{~m}, 5 \mathrm{~m}, 10 \mathrm{~m})$, as well as an analysis of variance (ANOVA) followed by a Tukey multiple mean comparison test to evaluate the effect of resolution on slope and aspect values. Pearson correlation coefficients were higher for the $5-\mathrm{m}$ and $10-\mathrm{m}$ resolutions than for the $1-\mathrm{m}$ resolution (Table 1). Results from the ANOVA and Tukey's tests indicated that there was no difference in aspect and slope determination between the $5-\mathrm{m}$ and $10-\mathrm{m}$ resolutions ( $p>0.05)$. Therefore, the 5-m resolution data were used for all further analyses.

We used ANOVAs to evaluate the effect of CPRS (before versus after) and mechanical site preparation on OLT. In cases of a significant F-value of the ANOVA, we also compared MSP treatments in terms of their effects on OLT using Tukey's tests. We used a model selection approach to assess the influence of the predictor variables (slope, aspect, MSP treatment, initial OLT conditions (before and post-CPRS OLT, and block distribution) on OLT reduction and microsite quality. We also included the presence of machinery trails in the models; it was considered as a binary variable (yes/no). Selection of the linear mixed models (nlme) and generalized linear models with a logistic regression (stats, rms) were based on the Akaike information criterion $\left(\mathrm{AIC}_{\mathfrak{c}} ;\right.$ AICcmodavg; Mazerolle 2006) (Tables 2 and 3).

Table 1. Matrix of Pearson correlation coefficients $\left(r_{p}\right)$ between organic layer thickness (OLT) before harvest (summer 2009) and topographic variables (slope and aspect) at different resolutions (1, 5 and $10 \mathrm{~m}$ ). Topographic variables were derived from DTM of 2010 LiDAR data.

\begin{tabular}{lccc}
\hline & \multicolumn{3}{c}{ Resolutions } \\
\cline { 2 - 4 } Topographic variables & $\mathbf{1 ~} \mathbf{~ m}$ & $\mathbf{5} \mathbf{~ m}$ & $\mathbf{1 0 ~} \mathbf{~}$ \\
\hline Slope & -0.11 & -0.26 & -0.26 \\
Aspect & 0.10 & 0.14 & 0.13 \\
\hline
\end{tabular}

All $r_{p}$ are significant at $p<0.05$. 
Table 2. Candidate models for the prediction of percent organic layer thickness (OLT) reduction.

\begin{tabular}{ll}
\hline Models & Prediction variables \\
\hline Global Model & $\begin{array}{l}\text { Treatment + post-CPRS OLT+ OLT before CPRS } \\
\text { +slope+aspect+ trail (yes/no)+block }\end{array}$ \\
Model 2 & $\begin{array}{l}\text { Treatment + post-CPRS OLT + OLT before CPRS } \\
\text { +slope+aspect }\end{array}$ \\
Model 3 & $\begin{array}{l}\text { Treatment + post-CPRS OLT + OLT before CPRS } \\
\text { + trail }\end{array}$ \\
Model 4 & Treatment + post-CPRS OLT + OLT before CPRS \\
Model 5 & Treatment + post-CPRS OLT + slope \\
Model 6 & Treatment + post-CPRS OLT + aspect \\
Model 7 & Treatment + post-CPRS OLT \\
\hline
\end{tabular}

CPRS: Careful logging with protection of advance growth and soils

We further used regression trees in order to segment and identify the complex interactions between predictor variables that affect OLT and abundance of quality microsites after MSP (rpart, tree, mvpart; Breiman et al. 1984). This nonparametric approach allows dividing (binary divisions) responses into small homogeneous groups (terminals) according to numerical and categorical predictors (Ouellette et al. 2005), and has been successfully used to explain the distribution of organic matter content in many soil types (e.g., Johnson et al. 2009, Häring et al. 2012). Regression trees were built using the models selected from the previous AIC analyses.

\section{Results}

Effects on organic layer thickness (OLT)

When comparing the variation of OLT between treatments in all blocks ( $\mathrm{n}=1472$ observations), we found that MSP (OLT = $24.79 \pm 4 \mathrm{~cm})$ significantly reduced OLT $(p<0.01)$ compared to pre-harvest values $(42.5 \pm 5 \mathrm{~cm})$ and compared to post-harvest values measured in blocks, protected strips and forwarder trails $(39.9 \pm 4.3 \mathrm{~cm})$. Organic layer thickness did not differ significantly $(p>0.3)$ before and post-CPRS (without MSP). Within the six blocks submitted to MSP, results showed a significant difference in pre-treatment (summer 2011) OLT $(p \leq 0.005)$ between blocks designated to receive T26 scarification $(35.5 \pm 3.7 \mathrm{~cm})$ and those selected to be treated by harrowing $(44.2 \pm 4 \mathrm{~cm})$. However, differences in OLT between T26 and harrowing blocks were no longer significant after treatment $(2012 ; p=0.4, \mathrm{~T} 26=31.5 \pm 5.2 \mathrm{~cm}$, harrowing $=23.2$ $\pm 3 \mathrm{~cm}$ ). Indeed, percent OLT reduction (relative to the postCPRS OLT) was higher in forest harrow blocks (41\%) than in T26 scarifier blocks ( $8 \%)(p<0.001$; Fig. 3$)$.

The best model (based on AIC ) showed that OLT reduction depended on post-CPRS OLT, type of MSP treatment (forest harrow, T26 scarifier) and slope (Model 5, Table 4). The regression tree analysis used to split and identify the interactions between those predictor variables resulted in nine terminals. The first split of the regression tree was found at a post-CPRS OLT $=19 \mathrm{~cm}$ (Fig. 4). The type of MSP treatment influenced both subsequent branches, whereas slope had a marginal influence in the post-CPRS OLT $<19 \mathrm{~cm}$ branch. In this branch, regression tree analysis showed high OLT reduction with the forest harrow (Terminal B, OLT
Table 3. Candidate models for the prediction of microsite quality.

\begin{tabular}{|c|c|}
\hline Models & Prediction variables \\
\hline Global model & $\begin{array}{l}\text { Treatment + post-CPRS OLT + OLT before CPRS } \\
\text { +slope+aspect + trail (yes/no)+block +\% OLT } \\
\text { reduction }\end{array}$ \\
\hline Model 2 & $\begin{array}{l}\text { Treatment + post-CPRS OLT + OLT before CPRS } \\
+ \text { slope+aspect + } \% \text { OLT reduction }\end{array}$ \\
\hline Model 3 & $\begin{array}{l}\text { Treatment }+ \text { post-CPRS OLT + OLT before CPRS } \\
+ \text { slope+ OLT reduction }\end{array}$ \\
\hline Model 4 & Treatment + post-CPRS OLT + OLT before CPRS \\
\hline Model 5 & Treatment + post-CPRS OLT + slope \\
\hline Model 6 & Treatment + post-CPRS OLT \\
\hline Model 7 & Treatment + post-CPRS OLT + trail \\
\hline Model 8 & Treatment + post-CPRS OLT + trail + slope + aspect \\
\hline Model 9 & Treatment \\
\hline Model 10 & post-CPRS OLT \\
\hline Model 11 & $\%$ OLT reduction \\
\hline
\end{tabular}

OLT: organic layer thickness; CPRS: Careful logging with protection of advance growth and soils

reduction of 2.2\%) and OLT accumulation with T26 scarifier (Terminal A, OLT accumulation of 138\%). We noted 10 observations of OLT accumulation following forest harrowing (in block \#7, Terminal C, OLT accumulation of 87\%). However, at post-CPRS OLT $>19 \mathrm{~cm}$, percent OLT reduction was relatively high (Terminals D, E, F, G, H, I). We also observed that at post-CPRS OLT $=27-44 \mathrm{~cm}$, percent OLT reduction was different between forest harrow (Terminal $\mathrm{F}$, OLT reduction of 22\%) and T26 scarifier (Terminal E, OLT reduction of 39\%). Table 5 shows the statistical values of terminals and number of observations. Tukey's test showed that percent OLT reduction was significantly different between most terminals ( 28 out of 36 pairs, $p \leq 0.05$ ). Terminals B, C and I showed fewer observations (22, 10 and 13 respectively) (Table 5).

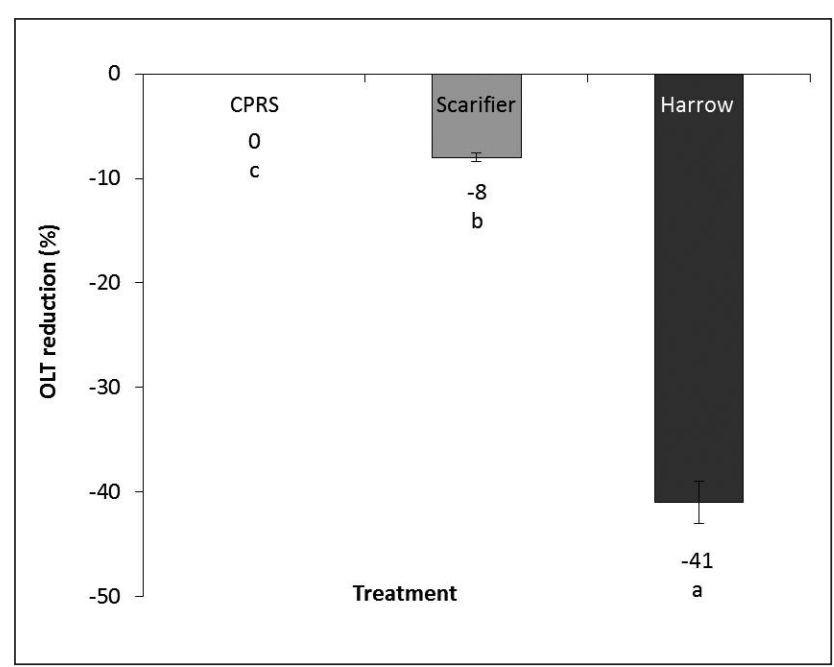

Fig. 3. Percent reduction of organic layer thickness (OLT) between treatments, compared to post-CPRS OLT values. Bars topped by the same letter are not statistically different $(p \geq 0.05)$. 
Table 4. Candidates model selection for the prediction of the percent organic layer thickness [OLT] reduction and microsite quality. Selected models are in bold.

\begin{tabular}{|c|c|c|c|c|c|c|}
\hline Response variables & Models & $\mathbf{K}$ & $\mathrm{AICc}$ & $\Delta \mathrm{AICc}$ & AICcWt & Cum.Wt \\
\hline \multirow[t]{7}{*}{$\%$ OLT reduction } & Model 5 & 6 & 2212.37 & 0 & 0.91 & 0.91 \\
\hline & Model 3 & 7 & 2217.83 & 5.46 & 0.06 & 0.97 \\
\hline & Model 6 & 6 & 2220 & 7.63 & 0.02 & 0.99 \\
\hline & Model 4 & 6 & 2221.78 & 9.42 & 0.01 & 1 \\
\hline & Model 2 & 7 & 2233.03 & 20.67 & 0 & 1 \\
\hline & Global model & 10 & 2237.07 & 24.7 & 0 & 1 \\
\hline & Model 7 & 6 & 2265.37 & 53.01 & 0 & 1 \\
\hline \multirow[t]{11}{*}{ Microsite quality } & Model 9 & 2 & 1305.69 & 0 & 0.81 & 0.81 \\
\hline & Model 2 & 7 & 1309.01 & 3.33 & 0.15 & 0.97 \\
\hline & Model 8 & 6 & 1312.59 & 6.91 & 0.03 & 0.99 \\
\hline & Global model & 9 & 1314.94 & 9.25 & 0.01 & 1 \\
\hline & Model 11 & 2 & 1338.52 & 32.83 & 0 & 1 \\
\hline & Model 4 & 4 & 1338.76 & 33.07 & 0 & 1 \\
\hline & Model 5 & 4 & 1342.43 & 36.75 & 0 & 1 \\
\hline & Model 3 & 6 & 1342.48 & 36.8 & 0 & 1 \\
\hline & Model 10 & 2 & 1343.62 & 37.93 & 0 & 1 \\
\hline & Model 6 & 3 & 1345.53 & 39.84 & 0 & 1 \\
\hline & Model 7 & 4 & 1345.99 & 40.3 & 0 & 1 \\
\hline
\end{tabular}

K: model parameters number, AICc: Akaike's Information Criterion corrected, $\triangle \mathrm{AICc}$ : AICc relative to the most parsimonious model, AICcWt: model weight. Cum.Wt: cumulative weight. The lowest AICc and Delta_AICc (0) values indicate the best model.

\section{Effects on microsite quality}

Model selection based on the AIC showed that microsite quality depended exclusively on MSP treatments (forest harrow, T26 scarifier) (Model 9, Table 4). Indeed, we were able to split microsite quality data according to the "treatment" variable using the regression tree analysis. Figure 5 shows that forest harrowing generated more good microsites than the T26 scarifier (70\% and 50\% respectively).

OLT reduction and microsite quality as a function of initial OLT We combined OLT reduction and microsite quality results into a decision tool that includes MSP techniques and OLT initial conditions, thus highlighting the percent of good and bad microsites for each terminal (Table 6). We noted that, when post-CPRS OLT was less than $19 \mathrm{~cm}$, forest harrow tended to reduce OLT on slopes $<6 \%$ and generated the highest percent of good microsites compared to T26 scarifier. With a post-CPRS OLT varying from $19 \mathrm{~cm}$ to $44 \mathrm{~cm}$, we observed that the forest harrow was still better than the T26 scarifier in terms of OLT reduction and good microsite creation. When post-CPRS OLT varied between $44 \mathrm{~cm}$ to $56 \mathrm{~cm}$, we observed that both treatments reduced OLT to the same extent, but that the T26 scarifier created the highest percent of good microsites. In the presence of $>56 \mathrm{~cm}$ of post-CPRS OLT, both MSP techniques resulted in equivalent OLT reduction, but the forest harrow created more good microsites than the T26 scarifier.

\section{Discussion}

Reduction of the organic layer thickness

Our results clearly demonstrate that the soil disturbance associated with MSP significantly reduces OLT compared to CPRS only, and confirm that CPRS alone is inefficient in reducing OLT (Lafleur et al. 2010). This lack of CPRS effect on organic layer thickness at the site level is explained by the restricted passage of harvesters and forwarders on trails, a practice which, by regulation, does not disturb more than $25 \%-33 \%$ of the harvested areas. Consequently post-CPRS OLT disruption is restricted to wheel tracks, leaving large nondisturbed areas between them.

Our results showed that the forest harrow reduced OLT significantly more than the T26 scarifier. Whereas T26 scarification creates trenches where the organic matter is removed and deposited on side berms, thus enhancing OLT thickness along the trenches, the forest harrow completely mixes the organic layers and incorporates it into the underlying soil (Prévost and Thiffault 2013). Moreover, while harrowing affects most of the site (particularly when a perpendicular double pass is used as here), trench scarification impacts are limited to less than $85 \%$ of the surface (LeBel et al. 2009). Differences between the capacity of forest harrowing and T26 scarification to reduce OLT were also probably related to the inherent characteristics of the equipment, particularly in terms of disc working depth; soil disturbance by forest harrows and T26 scarifiers can exceed $40 \mathrm{~cm}$ and $60 \mathrm{~cm}$ in natural soils depth, respectively (Örlander et al. 1990; Sutton 1993).

In addition to the characteristics of the equipment, treatment efficiency depends on soil moisture, stoniness, and slash abundance (Coates and Haeussler 1988, Von der Gönna 1992). For example, a 5\% slash cover may reduce MSP efficiency as discs have less contact with the soil (McGee and Birmingham 1997). Unfortunately, we have not precisely characterized these conditions in our study. However, accord-

Table 5. Statistics for different terminals corresponding to the percent reduction of organic layer thickness (OLT) (mean, median and standard deviation) obtained by regression tree analysis.

\begin{tabular}{lcccc}
\hline Terminals & N & Mean (\%) & SD & Median (\%) \\
\hline Terminal A & 55 & 139 & 133 & 122 \\
Terminal B & 22 & -2.2 & 116 & -29 \\
Terminal C & 10 & 86.7 & 159 & 33.5 \\
Terminal D & 160 & -4 & 72 & -8 \\
Terminal E & 220 & -22 & 57 & -19 \\
Terminal F & 149 & -39 & 45 & -44 \\
Terminal G & 197 & -44 & 44 & -49 \\
Terminal H & 162 & -64 & 26 & -64 \\
Terminal I & 13 & -86 & -94 & -94 \\
\hline
\end{tabular}




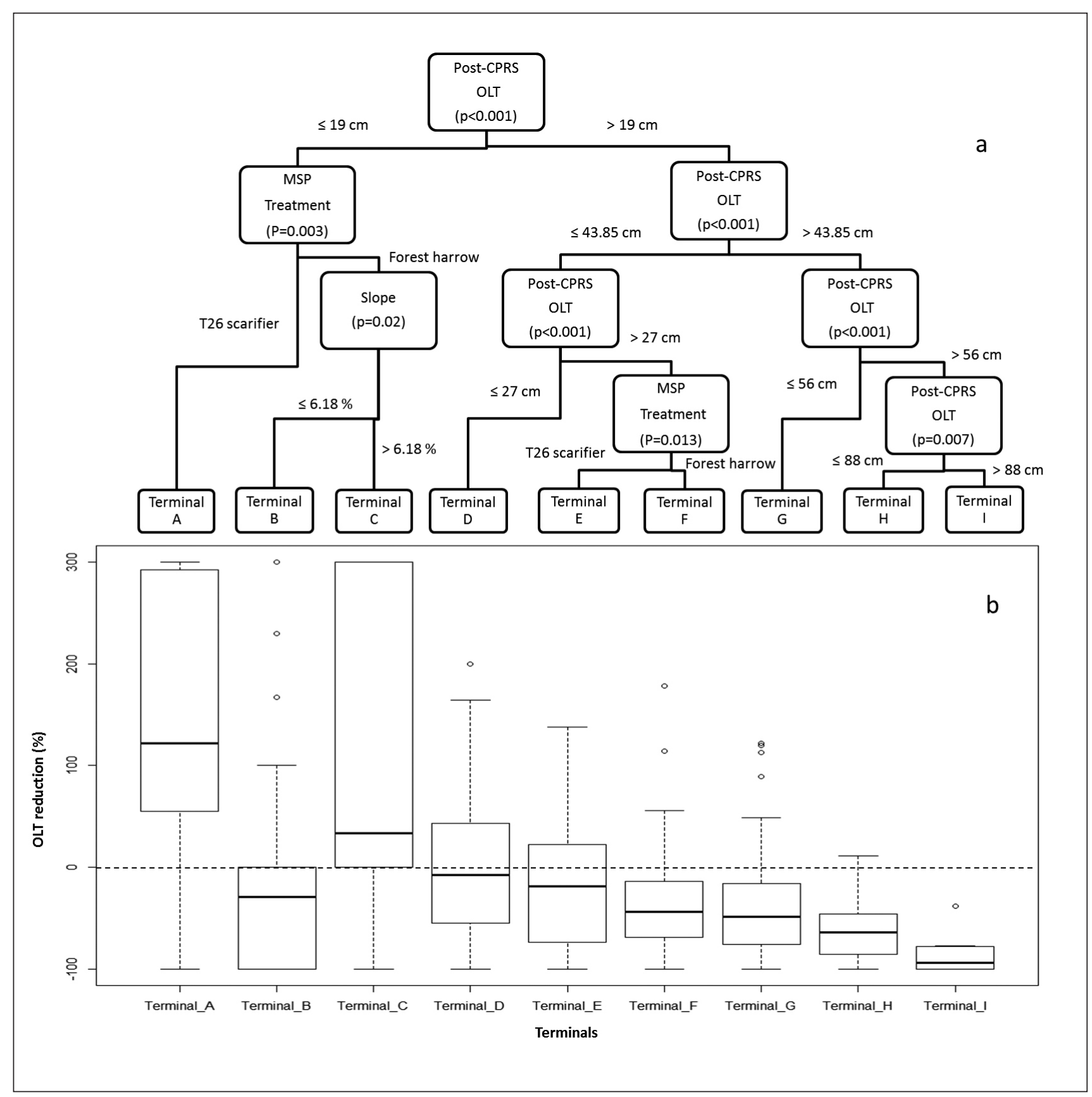

Fig. 4. (a) Results of binary division regression tree with nine terminals of percent organic layer thickness (OLT) reduction according to predictor variables (post-CPRS OLT, MSP treatments and slope). (b) Boxplots (median, minimum and maximum) presenting the variation of percent OLT reduction per terminal.

ing to our field observations, the soil of the study area presented a high moisture content (hence the important paludification) and a fairly high abundance of slash material representative of operational conditions (variable density among blocks) despite two consecutive slash material recovery conducted on these sites after CPRS.

We found that the efficiency of MSP techniques in reducing organic layer thickness depended primarily on post-CPRS organic layer thickness and slope, although the slope effect was marginal. The absence of slopes over $25 \%$ in our study area (which is characterized by a relatively flat terrain) probably explains why this effect was limited (McKinnon et al. 2002).
Laamrani et al. (2014) have documented the significant impact of slope on the paludification process. Therefore, we suspect that under relatively thin post-CPRS OLT conditions $(<19 \mathrm{~cm})$, the forest harrow is more sensitive to slope than T26 scarifier to OLT, because the discs (forest harrow) are in direct contact with the mineral soil. In addition, at this threshold $(<19 \mathrm{~cm})$, the forest harrow and T26 scarifier favour OLT accumulation ( $86 \%$ and $139 \%$ accumulation, respectively). This accumulation is due to the displacement of compressed organic matter that forms mounds of expanded OLT. In natural conditions, the organic layer is compressed by the weight of the overlying layers (mosses, fibric and mesic layer and 


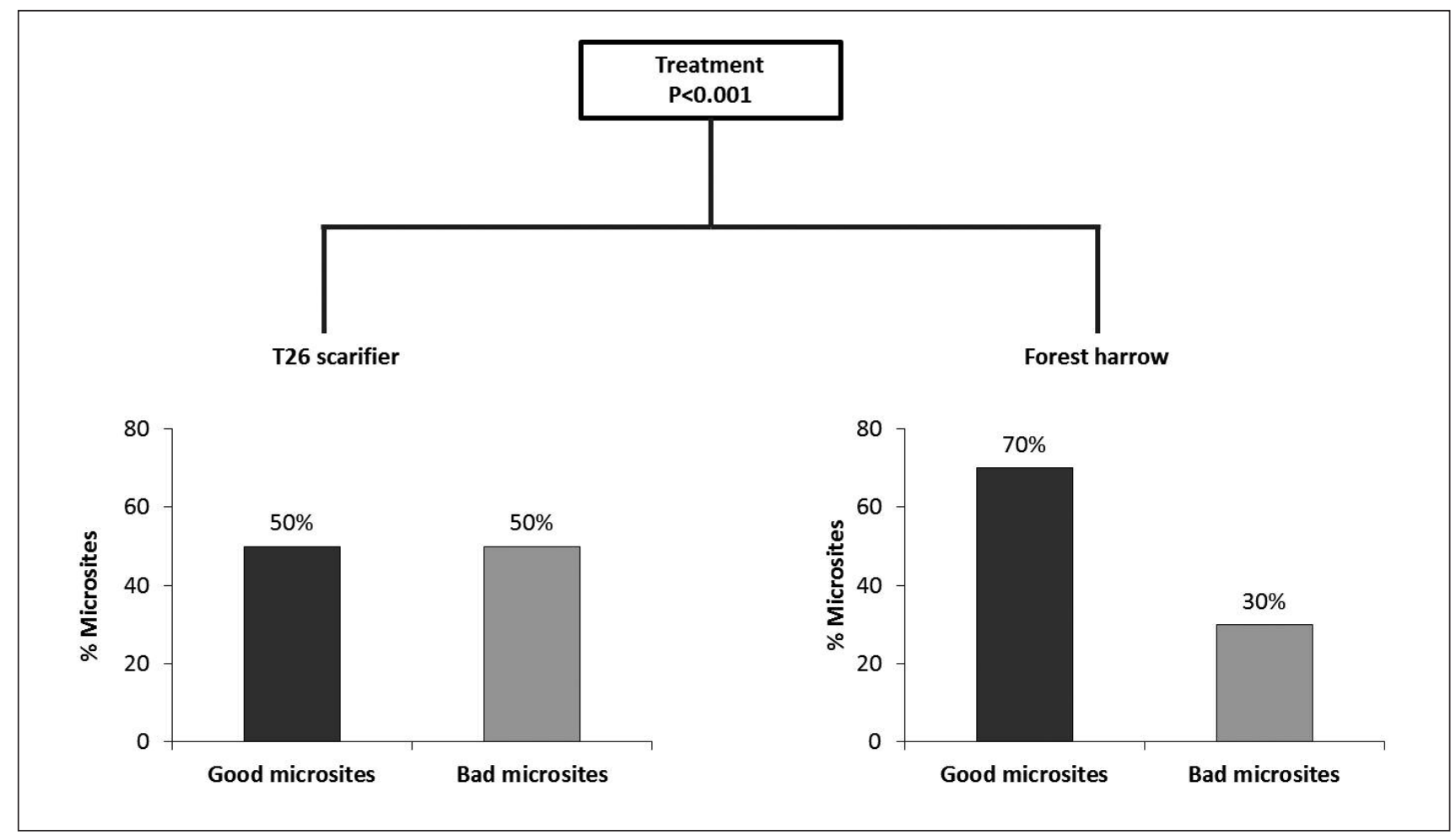

Fig. 5. Results of binary division regression tree for the percent of good/bad microsites across mechanical site preparation techniques.

Table 6. Average percent of organic layer thickness (OLT) reduction and of good/bad microsites per MSP technique, as a function of post-CPRS OLT, obtained by regression tree analysis. Negative and positive values of percent OLT reduction respectively indicate a predicted decrease and increase in absolute OLT after treatment.

\begin{tabular}{|c|c|c|c|c|c|c|c|c|c|}
\hline \multirow[b]{4}{*}{ Slope (\%) } & \multicolumn{9}{|c|}{ Post-CPRS OLT } \\
\hline & \multicolumn{3}{|c|}{ OLT $<19 \mathrm{~cm}$} & \multicolumn{2}{|c|}{$19 \mathrm{~cm}<$ OLT $<44 \mathrm{~cm}$} & \multicolumn{2}{|c|}{$44 \mathrm{~cm}<$ OLT $<56 \mathrm{~cm}$} & \multicolumn{2}{|c|}{$56 \mathrm{~cm}<$ OLT $<100 \mathrm{~cm}$} \\
\hline & \multicolumn{2}{|c|}{ Harrow } & \multirow{2}{*}{ T26 } & \multirow{2}{*}{ Harrow } & \multirow{2}{*}{ T26 } & \multirow{2}{*}{ Harrow } & \multirow{2}{*}{ T26 } & \multirow{2}{*}{ Harrow } & \multirow{2}{*}{ T26 } \\
\hline & $<6 \%$ & $>6 \%$ & & & & & & & \\
\hline \multirow[t]{2}{*}{ OLT reduction (\%) } & Reduces & $\begin{array}{l}\text { Tends to } \\
\text { accumulate }\end{array}$ & Accumulates & Reduces & Reduces & Reduces & Reduces & Reduces & Reduces \\
\hline & $-2.2 \%$ & $86 \%$ & $139 \%$ & $-39 \%$ & $-22 \%$ & $-44 \%$ & $-44 \%$ & $\begin{array}{l}-64 \% \\
\text { to }-86 \%\end{array}$ & $\begin{array}{l}-64 \% \\
\text { to }-86 \%\end{array}$ \\
\hline Good microsites & \multicolumn{2}{|c|}{$63 \%$} & $42 \%$ & $70-74 \%$ & $50-58 \%$ & $48 \%$ & $61 \%$ & $72 \%$ & $50 \%$ \\
\hline
\end{tabular}

humus) and by its water content. Decompression is linked to the mechanical response of porous materials (Sobac et al. 2011). Under relatively thick post-CPRS OLT conditions ( $>19$ $\mathrm{cm})$, the MSP equipment is more affected by the OLT than the slope, since the OLT regulates the level of the slope by making it either less steep or completely flat (Laamrani et al. 2013).

With a post-CPRS OLT $>44 \mathrm{~cm}$, differences in technique efficiency in reducing OLT disappeared. The limited potential for action of the discs of both machines with such thick OLT may explain why both types of equipment fail to adequately prepare the soil. This trend was even more evident when post-CPRS OLT exceeded $56 \mathrm{~cm}$. Therefore, in highly paludified and moist sites, the control of paludification by MSP techniques could be difficult and expensive (Lafleur et al. 2011) due to the inefficiency of most equipment in operating in low-bearing capacity conditions (high sinking risk), which requires the intervention of other complementary machines (e.g., excavator to extract machinery). 


\section{Microsite quality}

The model selection and regression tree analyses showed that microsite quality was strongly related to MSP techniques. At the microsite level (ca. $1 \mathrm{~m}^{2}$ ), MSP creates a variety of conditions with different physical, chemical and biological characteristics (Örlander et al. 1990, Sutton 1993). Given the particular field conditions associated with paludified sites, our results on microsite creation were lower than those generally reported under mesic field conditions (near 100\% for forest harrowing and $>85 \%$ for disc trenching; LeBel et al. 2009).

Good microsite output was particularly low for harrowing within the $44 \mathrm{~cm}-56 \mathrm{~cm}$ range of post-CPRS OLT. Within this thickness range, the passive discs of the forest harrow mainly deposited the organic layer over the mineral soil, without mixing the organic and mineral layers. The T26 scarifier created a higher proportion of good microsites than the forest harrow within the $44 \mathrm{~cm}-56 \mathrm{~cm}$ post-CPRS OLT range. It appears that the robust $1.35 \mathrm{~m}$ diameter-powered discs of the T26 scarifier were able to reach the mineral soil and mix its first $\mathrm{cm}$ with the organic matter.

In conditions where post-CPRS OLT was $>56 \mathrm{~cm}$, both machines exposed exclusively organic microsites due to the inaccessibility of the mineral soil at such depths. The forest harrow offered the highest proportion of good microsites, probably as a result of its capacity to mix the organic horizons (fibric, mesic, humic) and expose this homogeneous mixture over the entire treated area. Other factors not considered here (machinery horse power, number of discs, disc width, disc status) could have contributed significantly to the observed differences (Bedford and Sutton 2000).

Table 6 indicates an approximate planting potential (per hectare) in paludified conditions following MSP according to the pre-disturbance OLT thresholds. For example, if a forest harrow is used to prepare one hectare of paludified soil with an OLT of $\sim 37 \mathrm{~cm}$, post-treatment plantability will vary between $70 \%$ and $74 \%$. Assuming a $2 \mathrm{~m} \times 2 \mathrm{~m}$ spacing objective (2500 seedlings/ha), good microsites will be available for $1750-1850$ seedlings/ha.

\section{Limitations of the regression tree analyses}

The regression tree analyses that we used in this study have limitations that must be acknowledged. Indeed, with large data sets, regression trees can approximate all kinds of combinations and terminals by using rapid data fragmentation, with the inherent danger of producing terminals with very few observations and high variability (e.g., terminals B, C, I). Thus, it is generally recommended to proceed with prior discretization of variables with selection methods such as Breiman's random forest algorithm, AIC selection, or backward/forward/stepwise selection. With this in mind, we have thus limited the regression tree analyses to variables selected using the AIC approach, which gives us confidence in the quality of our interpretation. However, we acknowledge that the use of another selection method could have led to slightly different results.

\section{Conclusion}

In the Clay Belt, MSP appears as an effective solution against reversible paludification since it rapidly reduced OLT in conditions of relatively high initial organic layer thickness. Indeed, MSP can significantly reduce the thickness of the paludified layers (between $8 \%$ and $41 \%$ average reduction) while mixing the buried mineral soil with the upper organic material. Also, MSP favours the creation of suitable microsites for conifer regeneration, according to current operational standards. However, OLT reduction and microsite quality are strongly related to initial paludification conditions, MSP method, and slope. Overall, harrowing is usually better than T26 scarifier but offers limited performance on slopes exceeding $6 \%$ and within the $44 \mathrm{~cm}-56 \mathrm{~cm}$ range of postCPRS OLT.

\section{Acknowledgements}

This project was made possible with funding provided by NSERC (Natural Sciences and Engineering Research Council of Canada), the NSERC-UQAT-UQAM Chair in Sustainable Forest Management, and Tembec Inc. We also thank the Editor and two anonymous reviewers for their helpful comments, which enabled us to greatly improve an earlier version of the manuscript.

\section{References}

Bedford, L. and R. F. Sutton. 2000. Site preparation for establishing lodgepole pine in the sub-boreal spruce zone of interior British Columbia: The Bednesti trial, 10-year results. For. Ecol. Manage. 126(2): 227-238. doi:10.1016/S0378-1127(99)00090-0.

Bergeron, Y., P. Drapeau, S. Gauthier and N. Lecomte. 2007. Using knowledge of natural disturbances to support sustainable forest management in the northern Clay Belt. For. Chron. 83(3): 326-337. doi:10.5558/tfc83326-3.

Breiman, L., J. H. Friedman, R. A. Olshen and C. J. Stone. 1984. Classification and regression trees. The Wadsworth statistics/probability series. Wadsworth International Group, Belmont, CA.

Buitrago, M., A. Paquette, N. Thiffault, N. Bélanger and C. Messier. 2014. Early performance of planted hybrid larch: effects of mechanical site preparation and planting depth. New For. 1-19. doi:10.1007/s11056-014-9463-3.

Coates, D. and S. Haeussler. 1988. A guide to the use of mechanical site preparation equipment in north central British Columbia. Canadian Forestry Service, British Columbia Ministry of Forests and Lands.

Comont, L. 2006. Étude des processus de stockage de la matière organique et de régénération des tourbières dégradées après exploitation: sites du Russey (Jura français), de la Chaux d'Abel (Jura suisse) et de Baupte (Cotentin, France). Thèse de doctorat. Université d'Orléans, Orléans, France.

Environment Canada. 2011. Canadian climate normals, 1971-2000 [online]. Available from http://www.climate.weatheroffice.gc.ca/climate_normals. [Accessed 12 June 2012].

ESRI. 2011. ArcGIS Desktop: Release 10. Environmental Systems Research Institute, Redlands, USA, CA.

Fenton, N., N. Lecomte, S. Légaré and Y. Bergeron. 2005. Paludification in black spruce (Picea mariana) forests of eastern Canada: Potential factors and management implications. For. Ecol. Manage. 213(1-3): 151-159. doi:10.1016/j.foreco.2005.03.017.

Gower, S. T., R. E. McMurtrie and D. Murty. 1996. Aboveground net primary production decline with stand age: potential causes. Trends Ecol. Evol. 11(9): 378-382. doi:10.1016/0169-5347(96)10042-2. Häring, T., E. Dietz, S. Osenstetter, T. Koschitzki and B. Schröder. 2012. Spatial disaggregation of complex soil map units: A decisiontree based approach in Bavarian forest soils. Geoderma 185-186: 37-47. doi: 10.1016/j.geoderma.2012.04.001.

Harvey, B. and S. Brais. 2002. Effects of mechanized careful logging on natural regeneration and vegetation competition in the southeastern Canadian boreal forest. Can. J. For. Res. 32(4): 653-666. doi:10.1139/x02-006. 
Jutras, S., J. Begin, A.P. Plamondon and H. Hokka. 2007. Draining an unproductive black spruce peatland stand: 18-year post-treatment tree growth and stand productivity estimation. For. Chron. 83(5): 723-732. doi:10.5558/tfc83723-5.

Johnson, K.D., F.N. Scatena, A.H. Johnson and Y. Pan. 2009. Controls on soil organic matter content within a northern hardwood forest. Geoderma 148(3-4): 346-356. doi:10.1016/j.geoderma.2008.11.002. Laamrani, A., O. Valeria, L.Z. Cheng, Y. Bergeron and C. Camerlynck. 2013. The use of ground penetrating radar for remote sensing the organic layer - mineral soil interface in paludified boreal forests. Can. J. Remote Sens. 39(01): 74-88. doi:10.5589/m13-009.

Laamrani, A., O. Valeria, N. Fenton and Y. Bergeron. 2014. Landscape-scale influence of topography on organic layer accumulation in paludified boreal forests. For. Sci. 60(3): 579-590. doi:10.5849/ forsci.13-025.

Laamrani A., O. Valeria, Y. Bergeron, N. Fenton and L. Z. Cheng. 2015. Distinguishing and mapping permanent and reversible paludified landscapes in Canadian black spruce forests. Geoderma 237-238: 88-97. doi:10.1016/j.geoderma.2014.08.011.

Lafleur, B., N.J. Fenton, D. Paré, M. Simard and Y. Bergeron. 2010. Contrasting effects of season and method of harvest on soil properties and the growth of black spruce regeneration in the boreal forested peatlands of eastern Canada. Silva Fenn. 44(5): 799-813. doi:10.14214/sf.122.

Lafleur, B., D. Paré, N.J. Fenton and Y. Bergeron. 2011. Growth of planted black spruce seedlings following mechanical site preparation in boreal forested peatlands with variable organic layer thickness: 5-year results. Ann. For. Sci. 68(8): 1291-1302. doi:10.1007/s13595011-0136-5.

Lavoie, M., D. Paré, N.J. Fenton, A. Groot and K. Taylor. 2005. Paludification and management of forested peatlands in Canada: A literature review. Environ. Rev. 13(2): 21-50. doi:10.1139/a05-006. LeBel, L., D. Cormier, L. Desrochers, D. Dubeau, J. Dunnigan, J. Favreau, J.-F. Gingras, M. Hamel, P. Meek, J. Michaelsen, C. Sarthou and N. Thiffault. 2009. Chapitre 31. Opérations forestières et transport des bois. Dans Ordre des ingénieurs forestier du Québec, Manuel de foresterie, 2e ed. Éditions MultiMondes. Québec, QC, pp. 1245-1304.

Löf, M., D.C. Dey, R.M. Navarro and D.F. Jacobs. 2012. Mechanical site preparation for forest restoration. New For. 43(5-6): 825-848. doi:10.1007/s11056-012-9332-x.

Mazerolle, M.J. 2006. Improving data analysis in herpetology: using Akaike's Information Criterion (AIC) to assess the strength of biological hypotheses. Amphibia-Reptilia. 27(2): 169-180.doi: $10.1163 / 156853806777239922$.

McGee, G.G. and J.P. Birbingham. 1997. Decaying logs as germination sites in northern hardwood forests. North. J. Appl. For. 14(4): 178-182.

McKinnon, L.M., A.K. Mitchell and A. Vyse. 2002. The effects of soil temperature and site preparation on subalpine and boreal tree species: A bibliography. Information Report BC-X-394. Canadian Forest Service, Pacific Forestry Centre, Victoria, British Columbia. [MNRF] Ministère des Ressources naturelles et de la Faune. 2006. Qualité des plantations. Guide de l'évaluateur. Direction de la coordination des opérations régionales. Code de diffusion 2006-3004. Örlander, G., P. Gemmel and J. Hunt. 1990. Site preparation: A Swedish overview. British Columbia Ministry of Forests, FRDA Report 105.

Ouellette, M-H., J-L. Desgranges, P. Legendre and D. Borcard. 2005. Larbre de régression multivariable: classification d'assemblages doiseaux fondée sur les caractéristiques de leur habitat. Société Francophone de Classification, Montréal.

Payette, S. 2001. La stratigraphie. In S. Payette and L. Rochefort (eds.). Écologie des tourbières du Québec-Labrador. Les Presses de l'Université Laval, Québec, Canada, pp. 345-370.
Prescott, C.E., D.G. Maynard and R. Laiho. 2000. Humus in northern forests: Friend or foe? For. Ecol. Manage. 133(1): 23-36. doi:10.1016/S0378-1127(99)00295-9.

Prévost, M. and D. Dumais. 2003. Croissance et statut nutritif de marcottes, de semis naturels et de plants dépinette noire à la suite du scarifiage: résultats de 10 ans. Can. J. For. Res. 33(11): 2097-2107. doi:10.1139/x03-130.

Prévost, M. and N. Thiffault. 2013. La préparation de terrain. Chapitre 8. Le guide sylvicole du Québec, tome 2. Les concepts et lapplication de la sylviculture. C. Larouche, F. Guillemette, P. Raymond and J.-P. Saucier (eds.). Les Publications du Québec, Québec, QC, pp. 134-157.

R Development Core Team. 2012. R: A language and environment for statistical computing. R Foundation for Statistical Computing, Vienna, Austria. ISBN 3-900051-07-0, URL http://www.Rproject.org/.

Ryan, M.G., D. Binkley, J.H. Fownes, C.P. Giardina and R.S. Senock. 2004. An experimental test of the causes of forest growth decline with stand age. Ecol. Monogr. 74(3): 393-414. doi:10.1890/03-4037.

Salemaa, M., J. Derome and P. Nöjd. 2008. Response of boreal forest vegetation to the fertility status of the organic layer along a climatic gradient. Boreal Environ. Res. 13(SUPPL. B): 48-66.

Saucier, J.P., A. Robitaille and P. Grondin. 2009. Cadre bioclimatique du Québec. In Manuel de foresterie, $2^{\text {nd }}$ ed. R. Doucet and M. Côté (eds.). Ordre des ingénieurs forestiers du Québec, Éditions Multimondes, Québec, QC, pp. 186-205.

Simard, M., N. Lecomte,Y. Bergeron, P.Y Bernier and D. Paré. 2007. Forest productivity decline caused by successional paludification of boreal soils. Ecol. Applic. 17(6): 1619-1637. doi:10.1890/061795.1.

Simard, M., P.Y. Bernier, Y. Bergeron, D. Paré and L. Guérine. 2009. Paludification dynamics in the boreal forest of the James Bay Lowlands: Effect of time since fire and topography. Can. J. For. Res. 39(3): 546-552. doi:10.1139/X08-195.

Sirén, G. 1955. The development of spruce forest on raw humus sites in northern Finland and its ecology. Acta Forestalia Fennica 62.4.

Sobac, B., M. Colombani et Y. Forterre. 2011. Dynamique de mousses poroélastiques. Mécanique et industries. 12(03): 231-238. doi:10.1051/meca/2011115.

Soil Classification Working Group. 1998. The Canadian system of soil classification. 3rd ed. Publication 1646, Agriculture and AgriFood Canada, Ottawa, ON. Canada.

Sutherland, B.J. and F.F. Foreman. 1995. Guide to the use of mechanical site preparation equipment in Northwestern Ontario. Canadian Forest Service, Natural Resources Canada, Technical Report No. TR-87.

Sutton, R.F. 1993. Mounding site preparation: A review of European and North American experience. New For. 7(2): 151-192. doi:10.1007/BF00034198.

Thiffault, N., G. Cyr, G. Prégent, R. Jobidon and L. Charette. 2004. Régénération artificielle des pessières noires à éricacées: effets du scarifiage, de la fertilisation et du type de plants après 10 ans. For. Chron. 80(1): 141-149. doi:10.5558/tfc80141-1.

Thiffault, N. 2005. Choix du microsite sur sol scarifié en forêt boréal-quelques remarques. Ministère des Ressources naturelles et de la Faune-Direction de la recherche forestière.

Veillette, J.J. 1994. Evolution and paleohydrology of glacial lakes Barlow and Ojibway. Quaternary Sci. Rev. 13(9-10): 945-997. doi:10.1016/0277-3791(94)90010-8.

Von der Gönna, M.A. 1992. Fundamentals of mechanical site preparation. Forestry Canada and British Columbia Ministry Forestry, Victoria, BC, FRDA Rep. 178. 